Article

\title{
Providing Antibacterial Activity to Poly(2-Hydroxy Ethyl Methacrylate) by Copolymerization with a Methacrylic Thiazolium Derivative
}

\author{
Alexandra Muñoz-Bonilla *, Daniel López and Marta Fernández-García *(1) \\ Instituto de Ciencia y Tecnología de Polímeros (ICTP-CSIC), C/ Juan de la Cierva 3, 28006 Madrid, Spain; \\ daniel@ictp.csic.es \\ * Correspondence: sbonilla@ictp.csic.es (A.M.-B.); martafg@ictp.csic.es (M.F.-G.); Tel.: +34-91-258-7530 (M.F.-G.)
}

Received: 28 November 2018; Accepted: 16 December 2018; Published: 19 December 2018

\begin{abstract}
Antimicrobial polymers and coatings are potent types of materials for fighting microbial infections, and as such, they have attracted increased attention in many fields. Here, a series of antimicrobial copolymers were prepared by radical copolymerization of 2-hydroxyethyl methacrylate (HEMA), which is widely employed in the manufacturing of biomedical devices, and the monomer 2-(4-methylthiazol-5-yl)ethyl methacrylate (MTA), which bears thiazole side groups susceptible to quaternization, to provide a positive charge. The copolymers were further quantitatively quaternized with either methyl or butyl iodide, as demonstrated by nuclear magnetic resonance (NMR) and attenuated total reflection Fourier-transform infrared spectroscopy (ATR-FTIR). Then, the polycations were characterized by zeta potential measurements to evaluate their effective charge and by differential scanning calorimetry (DSC) and thermogravimetric analysis (TGA) to evaluate their thermal properties. The $\zeta$-potential study revealed that the quaternized copolymers with intermediate compositions present higher charges than the corresponding homopolymers. The cationic copolymers showed greater glass transition temperatures than poly(2-hydroxyethyl methacrylate) (PHEMA), with values higher than $100{ }^{\circ} \mathrm{C}$, in particular those quaternized with methyl iodide. The TGA studies showed that the thermal stability of polycations varies with the composition, improving as the content of HEMA in the copolymer increases. Microbial assays targeting Gram-positive and Gram-negative bacteria confirmed that the incorporation of a low number of cationic units into PHEMA provides antimicrobial character with a minimum inhibitory concentration (MIC) of $128 \mu \mathrm{g} \mathrm{mL}{ }^{-1}$. Remarkably, copolymers with MTA molar fractions higher than 0.50 exhibited MIC values as low as $8 \mu \mathrm{g} \mathrm{mL}^{-1}$.
\end{abstract}

Keywords: antimicrobial polymers; quaternary ammonium; 2-hydroxyethyl methacrylate; thermal stability

\section{Introduction}

In the last few years, antimicrobial polymers have attracted substantial scientific and industrial attention because of their unique properties and applications in the design and production of many materials, including medical devices, textiles, packaging, and purification systems [1-3]. Of special concern is bacterial contamination on the surfaces of medical devices, such as catheters or implants, which are responsible for many hospital-acquired infections (HAI), also known as nosocomial infections. The most common and serious HAIs are catheter-associated urinary tract infections, central line-associated bloodstream infections, ventilator-associated pneumonia, and surgical site infections, among others $[4,5]$. Coatings able to eliminate bacterial contamination on these material surfaces and, thus, prevent such infections have emerged as very efficient prophylactic strategies. These coatings can either repel microbes, avoiding microbial attachment, or kill microorganisms upon contact or in the 
surrounding by biocidal release [6]. In particular, self-disinfecting coatings with killing or bactericidal activity have demonstrated high efficiency and are typically obtained by incorporating antimicrobial agents, including antibiotics [7,8], antimicrobial peptides [9,10], silver and copper compounds [11,12], zinc oxide [13], titanium dioxide particles [14,15], etc., onto the surface. Alternatively, the use of antimicrobial polymers as contact-active coatings with inherent biocidal activity has gained importance, because antimicrobial polymers offer some advantages, such as chemical stability, high and long-term activity, low toxicity, and reduced potential to generate resistance [16,17]. Most of these antimicrobial polymers are polycations, in particular polymers with quaternary ammonium groups $[18,19]$, which are able to interact with the negatively charged bacterial wall, disrupting the integrity of the membrane and leading to the death of the bacteria. Recently, we developed a series of polycations based on polymethacrylates bearing pendant 1,3-thiazolium groups, which have demonstrated high activity against a broad spectrum of bacteria [20-22]. In addition, antimicrobial polymeric coatings have been prepared from these polycations by blending with hydrophobic polymers typically used in medical devices, such as polyacrylonitrile or polystyrene [23-25].

Concerning hydrophilic polymer materials, poly(2-hydroxyethyl methacrylate) (PHEMA) is one of the most widely used in the manufacture of medical devices, such as contact and intraocular lenses, and medical device coatings [26,27], because it exhibits blood and cell biocompatibility, low cytotoxicity, and thrombogenicity $[28,29]$. In addition, a variety of antimicrobial agents has been included into hydrogels and materials based on PHEMA to provide biocidal character as an additional property [26,30-32]. Herein, we prepared copolymers systems composed of 2-hydroxyethyl methacrylate (HEMA) and a methacrylic monomer bearing thiazolium moieties (MTARI) with the purpose of incorporating antimicrobial properties into PHEMA. Several copolymer compositions were prepared and evaluated for an adequate balance of structural, thermal, and antimicrobial properties.

\section{Results and Discussion}

\subsection{Synthesis of Cationic Polyelectrolytes: P(MTARI-co-HEMA) Copolymers}

First, the synthesis of P(MTA-co-HEMA) copolymers was performed by free radical polymerization of HEMA and 2-(4-methylthiazol-5-yl)ethyl methacrylate (MTA) comonomers, using different feed molar ratios, i.e., feed molar fraction of MTA, $\mathrm{f}_{\mathrm{MTA}}=0.0,0.2,0.4,0.6,0.8$, and 1.0 (Scheme 1).

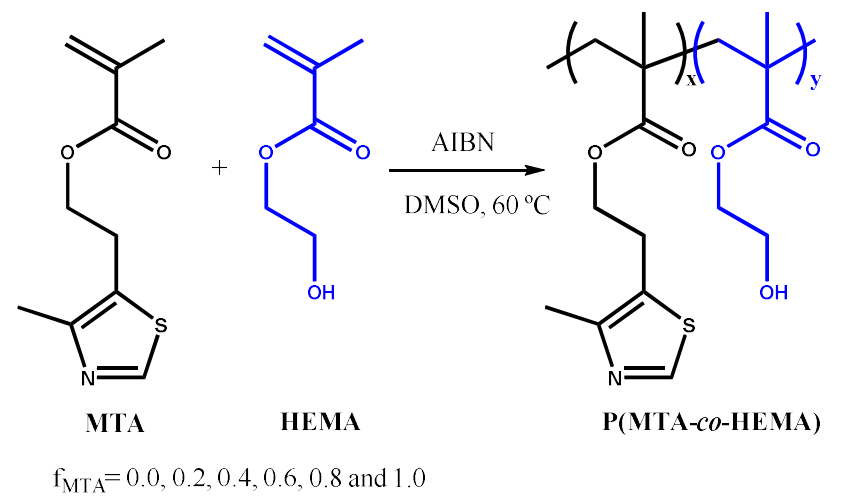

Scheme 1. Schematic representation of the synthesis of the P(MTA-co-HEMA) copolymers with different molar compositions. AIBN: 2,2'-azobisisobutyronitrile.

The copolymerizations almost reached full conversion after $24 \mathrm{~h}$ for all the initial $\mathrm{f}_{\mathrm{MTA}}$, which was confirmed gravimetrically and by ${ }^{1} \mathrm{H}-\mathrm{NMR}$ (the double bonds completely disappeared from the bulk of the reactions). Similarly, the molar fractions of MTA in the obtained copolymers ( $\mathrm{F}_{\mathrm{MTA}}$ ) were determined by ${ }^{1} \mathrm{H}-\mathrm{NMR}$, and as expected, these values were found to be very close to the $f_{\text {MTA }}$ values (Table 1$)$ as the conversion was nearly complete $\left(f_{M T A} \cong F_{M T A}\right)$. Table 1 summarizes the average molecular weight $\left(\mathrm{M}_{n}\right)$ and the polydispersity indexes (PDI) of the P(MTA-co-HEMA) 
copolymers determined by gel permeation chromatography (GPC). The molecular weights ranged from 35 to $87 \mathrm{kDa}$, while the PDI values were around 1.9-2.4, similar to those typically obtained in radical polymerization.

Table 1. Characterization of the P(MTA-co-HEMA) copolymers.

\begin{tabular}{cccc}
\hline $\mathbf{f}_{\mathbf{M T A}}$ & $\mathbf{F}_{\mathbf{M T A}}$ & $\mathbf{M}_{\mathbf{n}} \mathbf{( k D a )}$ & $\mathbf{P D I}$ \\
\hline 0.00 & 0.00 & 86.8 & 2.1 \\
0.20 & 0.18 & 60.8 & 2.0 \\
0.40 & 0.37 & 59.2 & 2.4 \\
0.60 & 0.56 & 42.6 & 2.2 \\
0.80 & 0.76 & 34.5 & 2.2 \\
1.00 & 1.00 & 36.6 & 1.9 \\
\hline
\end{tabular}

Subsequently, the corresponding polycations with different charge balances were prepared by $\mathrm{N}$-alkylation of the P(MTA-co-HEMA) copolymers with either butyl or methyl iodide, as shown in Scheme 2.

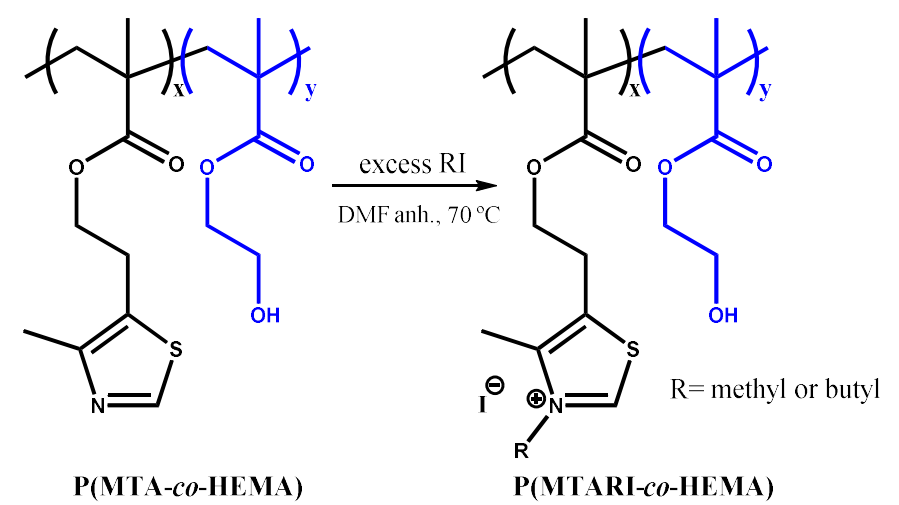

Scheme 2. Schematic representation of the quaternization of the P(MTARI-co-HEMA) polycations with alkyl iodide (RI). DMF: N,N-dimethylformamide.

To ensure the complete quaternization of all the thiazole groups present in the copolymers, the reaction was carried out with an excess of the alkylating agent at $70{ }^{\circ} \mathrm{C}$. After one week, complete quaternization was reached for all the cases as revealed by ${ }^{1} \mathrm{H}-\mathrm{NMR}$ spectra. As an example, Figure 1 depicts the spectra of the quaternized copolymers with butyl iodide, P(MTABuI-co-HEMA), and their corresponding homopolymers, PHEMA and PMTABuI. The MTA homopolymer (PMTA) spectrum is also depicted for comparative purposes to visualize the shift alteration produced by the protonation. It can be clearly seen that the signals corresponding to the aromatic protons of 1,3-thiazole, $-\mathrm{N}=\mathrm{CH}-\mathrm{S}$, at $\sim 8.8$ ppm shifted to $\sim 10.1-10.2$ ppm after the $N$-alkylation to obtain 1,3-thiazolium group, $-\mathrm{N}^{+}=\mathrm{CH}-\mathrm{S}$, which confirmed that all the modifications were achieved quantitatively [33,34]. In addition, new signals appeared at $\sim 4.4 \mathrm{ppm}$ due to the alkylating agent (i.e., $-\mathrm{N}^{+}-\mathrm{CH}_{2}-$ in the case of butyl iodide). The intensity of this signal increased as the content of MTA increased in the copolymer, that is, with increasing values of $\mathrm{F}_{\mathrm{MTA}}$. This event was concomitant with a decrease in the intensity of the signals attributed to the HEMA units, such as the peak at $4.8 \mathrm{ppm}$ that corresponded to the proton of the hydroxyl group. The copolymers were also characterized by ATR-FTIR spectroscopy. As an example, Figure 2 shows the spectra of the unquaternized and quaternized copolymers with both alkylating agents with an active comonomer composition of 0.8 , viz. P( $\mathrm{MTA}_{0.8}$-co-HEMA $\left.\mathrm{H}_{0.2}\right)$,

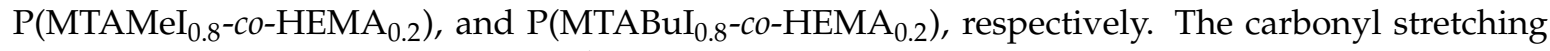
vibration $(\mathrm{C}=\mathrm{O})$ at around $1720 \mathrm{~cm}^{-1}$, characteristic of methacrylic monomers, the $\mathrm{O}-\mathrm{H}$ stretching region around $3700-3100 \mathrm{~cm}^{-1}$, and the $\mathrm{C}-\mathrm{O}$ band at ca. $1250 \mathrm{~cm}^{-1}$, typical of HEMA polymers, can be observed clearly in the spectra. The band corresponding to the $\mathrm{C}=\mathrm{N}-$ stretching vibration of MTA 
appeared at $1550 \mathrm{~cm}^{-1}$. This band vanished when the copolymers were modified with the alkyl iodine agents, and a new band emerged at ca. $1590 \mathrm{~cm}^{-1}$, characteristic of the $\mathrm{C}=\mathrm{N}^{+}-$stretching vibration.

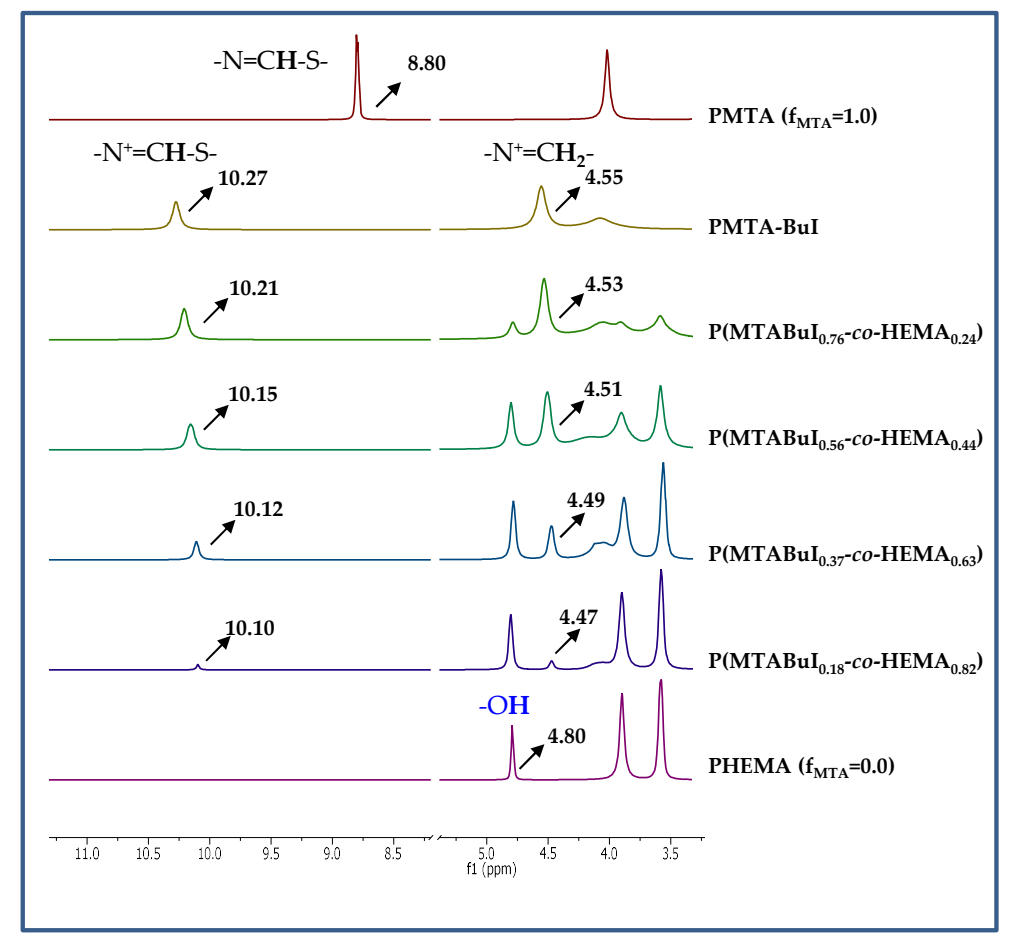

Figure 1. Schematic representation of the preparation of the P(MTARI-co-HEMA) polycations by quaternization with alkyl iodide (RI). Representative region of ${ }^{1} \mathrm{H}-\mathrm{NMR}$ spectra in DMSO-d6 of P(MTABuI-co-HEMA), PMTA, PMTABuI, and PHEMA.

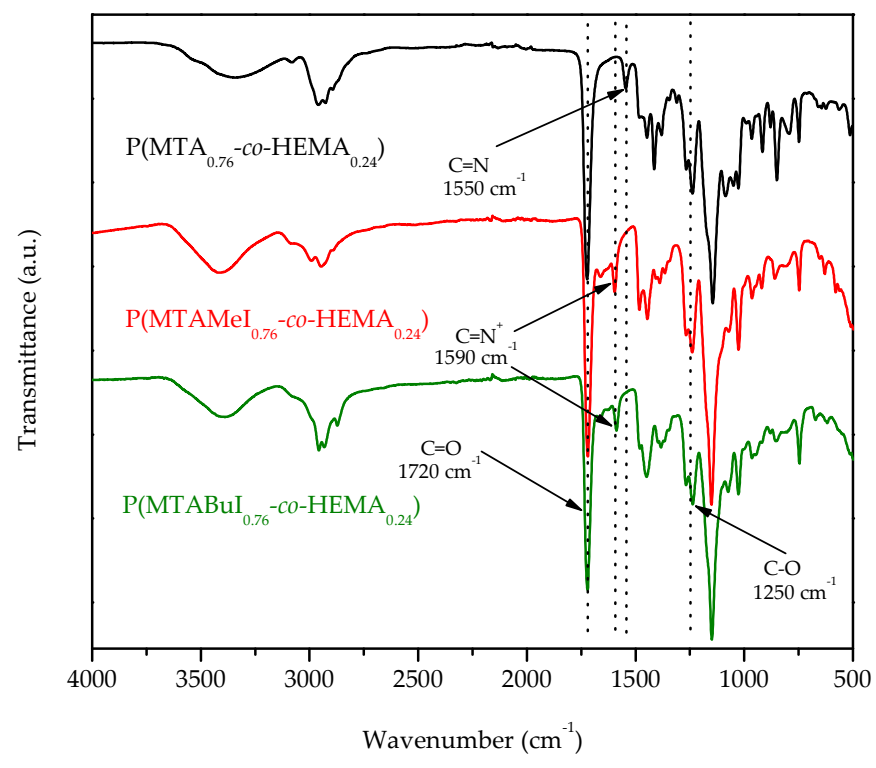

Figure 2. Attenuated total reflection Fourier-transform infrared spectroscopy (ATR-FTIR) spectra of $\mathrm{P}\left(\mathrm{MTA}_{0.8}-c o-\mathrm{HEMA}_{0.2}\right), \mathrm{P}\left(\mathrm{MTAMeI}_{0.8}-\mathrm{co}-\mathrm{HEMA}_{0.2}\right)$, and $\mathrm{P}\left(\mathrm{MTABuI}_{0.8}-c o-\mathrm{HEMA}_{0.2}\right)$.

\subsection{Characterization of the Synthetized Copolymers: P(MTA-co-HEMA), and P(MTARI-co-HEMA)}

Once the copolymer precursors, P(MTA-co-HEMA), and the polycations P(MTARI-co-HEMA) were successfully prepared, they were characterized to estimate their antimicrobial potential. It is well known that such activity is dependent on different parameters, such as the nature of the charge; the hydrophobic groups; the balance of cationic to hydrophobic moieties; the polymer composition; 
and the molecular weight $[1,35,36]$. Then, the $\zeta$-potential of the polycations was determined, and the obtained values are represented in Figure 3.
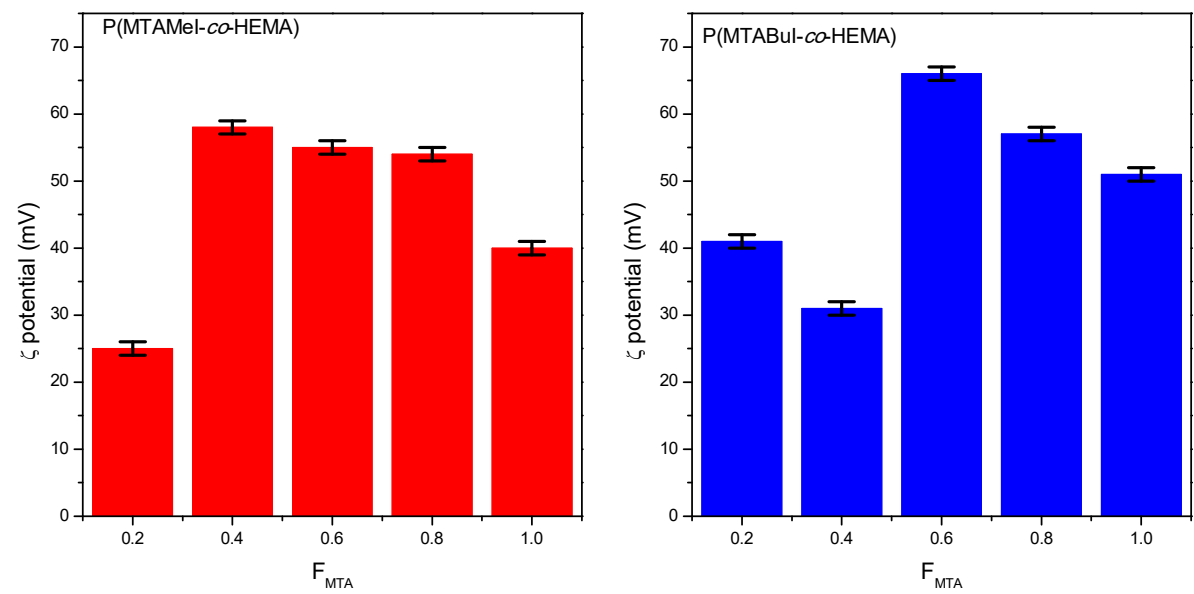

Figure 3. Variation of the $\zeta$-potential of the quaternized copolymer series as a function of the composition.

Interestingly, the compositions with higher contents of MTA presented greater zeta potential values than their corresponding quaternized homopolymers. They presented values near to +60 or higher, which indicated the good stability of the aggregation in comparison with the homopolymers, especially with respect to the PMTAMeI, which has moderate stability with a $\zeta$-potential of +40 . In fact, the PMTABuI homopolymer was more stable and positively charged than the PMTAMeI: therefore, higher antimicrobial activity was to be expected.

Subsequently, the thermal properties of the obtained copolymers were analyzed given that they were of great importance for the applicability of these antimicrobial polymers. The copolymers were first analyzed by differential scanning calorimetry (DSC), and the glass transition temperatures, $\mathrm{T}_{\mathrm{g}}$, are given in Table 2. Figure $4 \mathrm{a}$ displays the DSC curves of the unquaternized copolymers, while Figure $4 \mathrm{~b}$ represents the $T_{g}$ variation of all the series as a function of the copolymer composition, $\mathrm{F}_{\mathrm{MTA}}$.

(a)

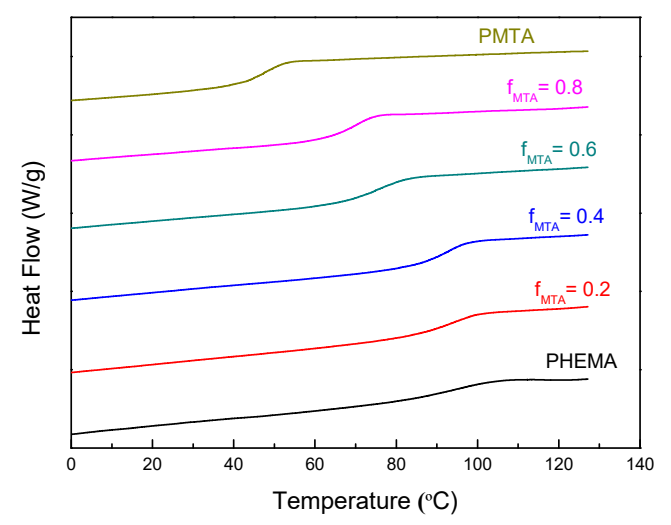

(b)

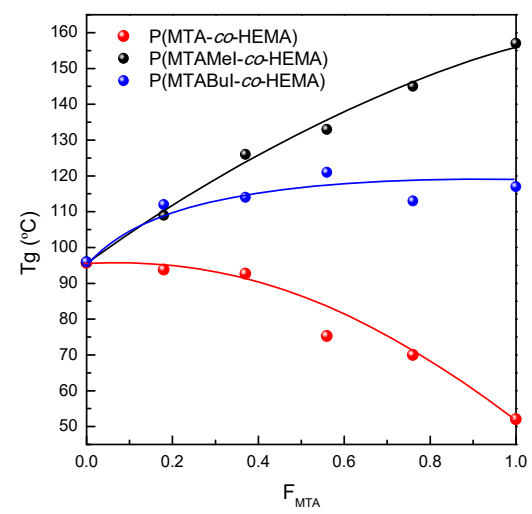

Figure 4. (a) Differential scanning calorimetry (DSC) curves of the pristine (PMTA-co-HEMA) copolymers; and (b) The glass transition temperatures of the P(MTA-co-HEMA), P(MTAMeI-co-HEMA), and P(MTABuI-co-HEMA) copolymers as a function of the MTA or MTARI content in the copolymer, $\mathrm{F}_{\mathrm{MTA}}$.

From these data, it was observed that the $\mathrm{T}_{\mathrm{g}}$ values of the copolymers shifted to lower temperatures as the content of MTA, $\mathrm{F}_{\mathrm{MTA}}$, increased up to $49{ }^{\circ} \mathrm{C}$ for the PMTA homopolymer. In contrast, the polycations obtained after quaternization followed the contrary trend; their $\mathrm{T}_{\mathrm{g}}$ increased with the amount of the MTARI cationic units for both series of copolymers-those 
quaternized with methyl iodide (P(MTAMeI-co-HEMA)) and those quaternized with butyl iodide (P(MTABuI-co-HEMA)). Also, both series of cationic copolymers exhibited greater $\mathrm{T}_{\mathrm{g}}$ than the PHEMA homopolymer. It was noticeable that the P(MTAMeI-co-HEMA) copolymers achieved higher $\mathrm{T}_{\mathrm{g}}$ values in comparison with the P(MTABuI-co-HEMA) series due to the effect of the length of the alkylating agent. The incorporation of a long and flexible alkyl chain, such as a butyl group, improved the mobility of the copolymers and reduced their $\mathrm{T}_{\mathrm{g}}$.

Table 2. Thermal characteristic parameters determined by DSC and TGA of the synthesized copolymers. Glass transition temperature, $\mathrm{T}_{\mathrm{g}}$; initial degradation temperature, $\mathrm{T}_{\mathrm{d}}$ onset; temperature of the maximum rate of weight loss for each step, $\mathrm{T}_{\mathrm{d}}{ }^{\mathrm{max}}$; and the rate of weight loss for each step, $-\mathrm{dw} / \mathrm{dT}$.

\begin{tabular}{|c|c|c|c|c|c|c|c|c|}
\hline $\mathbf{F}_{\text {MTA }}$ & $\begin{array}{c}\mathrm{T}_{\mathrm{g}} \\
\left({ }^{\circ} \mathrm{C}\right)\end{array}$ & $\begin{array}{c}\mathrm{T}_{\mathrm{d}} \text { onset } \\
\left({ }^{\circ} \mathrm{C}\right)\end{array}$ & $\begin{array}{c}\mathrm{T}_{\mathrm{d}} \max 1 \\
\left({ }^{\circ} \mathrm{C}\right)\end{array}$ & $\begin{array}{c}-\mathrm{dw}_{1} / \mathrm{dT} \\
\left(\% /{ }^{\circ} \mathrm{C}\right)\end{array}$ & $\begin{array}{c}\mathrm{T}_{\mathrm{d}} \max 2 \\
\left({ }^{\circ} \mathrm{C}\right)\end{array}$ & $\begin{array}{c}-\mathrm{dw}_{2} / \mathrm{dT} \\
\left(\% /{ }^{\circ} \mathrm{C}\right)\end{array}$ & $\begin{array}{c}\mathrm{T}_{\mathrm{d}} \max 3 \\
\left({ }^{\circ} \mathrm{C}\right)\end{array}$ & $\begin{array}{c}-\mathrm{dw}_{3} / \mathrm{dT} \\
\left(\% /{ }^{\circ} \mathrm{C}\right)\end{array}$ \\
\hline \multicolumn{9}{|c|}{ P(MTA-co-HEMA) } \\
\hline 0.00 & 96 & 259.0 & 178.5 & 0.03 & - & - & 400.0 & 0.99 \\
\hline 0.18 & 94 & 288.0 & 175.0 & 0.03 & 328.5 & 0.45 & 441.5 & 1.26 \\
\hline 0.37 & 92 & 300.5 & 100.0 & 0.02 & 327.5 & 0.62 & 432.5 & 1.17 \\
\hline 0.56 & 75 & 301.0 & - & - & 341.0 & 0.74 & 435.0 & 0.91 \\
\hline 0.76 & 70 & 294.0 & - & - & 350.0 & 0.98 & 426.0 & 0.65 \\
\hline 1.00 & 49 & 300.0 & - & - & 366.5 & 1.08 & 413.5 & 0.34 \\
\hline \multicolumn{9}{|c|}{ P(MTAMeI-co-HEMA) } \\
\hline 0.00 & 96 & 259.0 & 178.5 & 0.03 & - & - & 400.0 & 0.99 \\
\hline 0.18 & 109 & 185.0 & 237.5 & 0.18 & - & - & 420.5 & 1.05 \\
\hline 0.37 & 126 & 186.5 & 228.5 & 0.39 & - & - & 404.0 & 0.71 \\
\hline 0.56 & 133 & 196.5 & 220.5 & 0.75 & 320.0 & 0.38 & 429.5 & 0.71 \\
\hline 0.76 & 145 & 205.5 & 228.5 & 0.89 & 329.5 & 0.37 & 422.0 & 0.52 \\
\hline 1.00 & 157 & 209.5 & 235.5 & 1.12 & 341.5 & 0.41 & 421.5 & 0.36 \\
\hline \multicolumn{9}{|c|}{ P(MTABuI-co-HEMA) } \\
\hline 0.00 & 96 & 259.0 & 178.5 & 0.03 & - & - & 400.0 & 0.99 \\
\hline 0.18 & 112 & 220.0 & 250.5 & 0.37 & - & - & 433.5 & 1.32 \\
\hline 0.37 & 114 & 225.0 & 247.5 & 0.96 & - & - & 432.0 & 0.89 \\
\hline 0.56 & 121 & 222.0 & 242.5 & 1.20 & - & - & 426.0 & 0.73 \\
\hline 0.76 & 113 & 221.0 & 244.5 & 1.43 & - & - & 419.0 & 0.55 \\
\hline 1.00 & 117 & 229.0 & 251.0 & 1.80 & - & - & 418.0 & 0.36 \\
\hline
\end{tabular}

Then, the thermal stability of the different series was analyzed by TGA under an inert atmosphere. Figure 5 displays the TGA curves of the unquaternized and quaternized copolymer, and the thermal degradation parameters are collected in Table 2. The degradation of PHEMA took place in one single stage, considering that a previous step of water elimination occurred because of the hygroscopic character of the polymer (ca. 2-3\%). The literature has explained that the resulting product of this breakdown is mainly the HEMA monomer [37-39]. PMTA presented two main stages, and contrary to HEMA, in which depolymerization was the main process, the degradation seemed to be by random chain scission as with poly(methyl methacrylate). In the case of the unmodified copolymers, the behavior was dependent on the HEMA/MTA content. Those copolymers with HEMA predominance presented hygroscopic tendencies and intermediate behaviors between both homopolymer parents. The first main stage, at temperatures higher than $300^{\circ} \mathrm{C}$, is shifted to higher temperatures as the MTA increased, while in the second step, the temperatures decreased. Nevertheless, the stability was improved by the presence of HEMA in the copolymer.

This behavior was more evident in both the quaternized copolymer series. Figure $5 b, c$ show that the incorporation of the HEMA units into the copolymers expanded the thermal stability, which could extend the applicability of these antimicrobial materials. In the case of methyl iodide incorporation, the degradation occurred in three stages instead of the two appearing in the case of butyl iodide. Therefore, the quaternization with a longer alkyl agent stabilized the macromolecular structure of 
the cationic copolymers. In contrast, the polycations obtained after the quaternization followed the contrary trend; their $\mathrm{T}_{\mathrm{g}}$ increased with the amount of the MTARI cationic units for both series of copolymers-those quaternized with methyl iodide (P(MTAMeI-co-HEMA)) and those quaternized with butyl iodide (P(MTABuI-co-HEMA)). Also, both series of cationic copolymers exhibited greater $\mathrm{T}_{\mathrm{g}}$ than the PHEMA homopolymer, whose value was almost $100{ }^{\circ} \mathrm{C}$ due to the strong inter- and intramolecular interactions [37,40]. It is noticeable that the P(MTAMeI-co-HEMA) copolymers achieved higher $\mathrm{T}_{\mathrm{g}}$ values in comparison with the copolymers quaternized with butyl iodide because of the effect of the length of the alkylating agent. The incorporation of a long and flexible alkyl chain, such as a butyl group, improved the mobility of the copolymers and reduced their $\mathrm{T}_{\mathrm{g}}$.

(a)

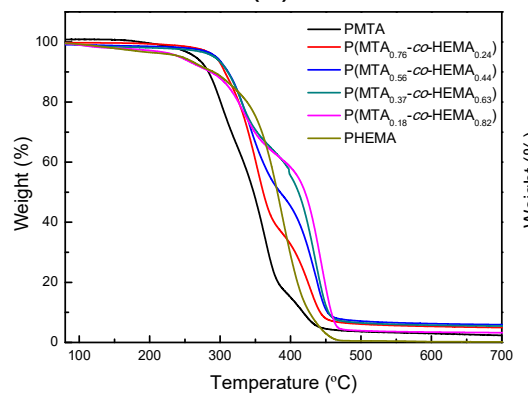

(b)

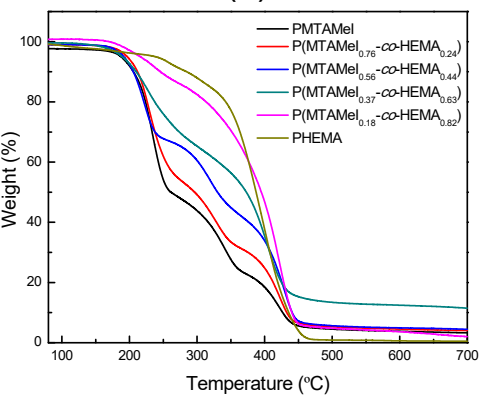

(c)

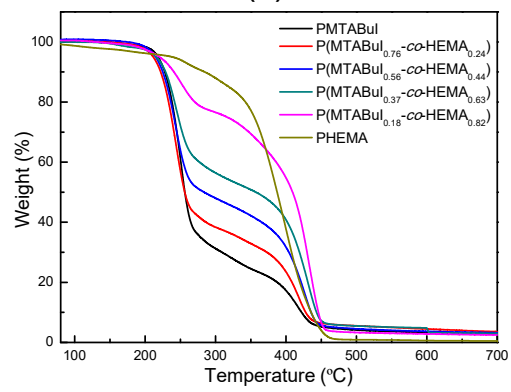

Figure 5. Thermogravimetric analysis of the (a) P(MTA-co-HEMA), (b) P(MTAMeI-co-HEMA), and (c) P(MTABuI-co-HEMA) copolymers.

\subsection{Antibacterial Activity Studies}

The antimicrobial activity of the prepared polycations, the P(MTAMeI-co-HEMA) and P(MTABuI-co-HEMA) copolymers, was evaluated against the model bacterial strains, Gram-positive Staphylococcus aureus and Gram-negative Pseudomonas aeruginosa. These polymers were also tested against fungi Candida parapsilosis, but they were not effective in the opposite behavior when MTA was copolymerized with acrylonitrile, a hydrophobic monomer [21]. Concretely, the microbroth dilution reference method [41-43] was used, obtaining the minimum inhibitory concentration (MIC) values collected in Table 3. As expected, the homopolymers, PMTAMeI and PMTABuI, exhibited significant antimicrobial activity with very low MIC values, as previously reported [20]. The homopolymer quaternized with butyl iodide showed improved activity against the Gram-negative bacteria in comparison with the methylated polymer, because it augments the hydrophobic balance of the copolymers [35]. In effect, several studies have demonstrated that the incorporation of certain contents of hydrophobic moieties, reaching an adequate hydrophobic/hydrophilic balance, improves the antimicrobial activity of the polymer, because the process facilitates the pass through the hydrophobic cytoplasmic membrane [44,45].

On the other hand, when biocompatible HEMA units are incorporated into the copolymer, the activity tends to diminish. This is due to the decrease in the positive charge density of the corresponding polycations as a result of the incorporation of a non-active monomer. Nevertheless, the copolymers mainly based on HEMA, with MTARI contents as low as $\mathrm{F}_{\mathrm{MTA}}=0.18$, still exhibited significant activity-MIC values of $128 \mu \mathrm{g} \mathrm{mL}^{-1}$. Again, the copolymers containing butyl groups showed better activities than the copolymers quaternized with methyl iodide. Remarkably, the copolymers quaternized with butyl iodide maintained their excellent activity up to a relatively high content of HEMA, with MIC $=8 \mu \mathrm{g} \mathrm{mL}^{-1}$ for the $\mathrm{F}_{\mathrm{MTA}}$ value of 0.56 . In this case, the copolymers might have adopted in-solution conformations in which their positive charges were highly accessible to bacterial membrane. 
Table 3. Minimum inhibitory concentration (MIC) of the quaternized copolymers, $\mathrm{P}(\mathrm{MTAMeI}-\mathrm{co}$-HEMA) and P(MTABuI-co-HEMA), against Gram-positive Staphylococcus aureus and Gram-negative Pseudomonas aeruginosa.

\begin{tabular}{ccc}
\hline \multirow{2}{*}{$\mathbf{F}_{\text {MTA }}$} & \multicolumn{2}{c}{ MIC $\left(\mu \mathrm{g} \mathrm{mL}^{-\mathbf{1}}\right)$} \\
\cline { 2 - 3 } & S. aureus & P. aeruginosa \\
\hline \multicolumn{3}{c}{ P(MTAMeI-co-HEMA) } \\
\hline 0.18 & 128 & 128 \\
0.37 & 128 & 128 \\
0.56 & 128 & 128 \\
0.76 & 8 & 32 \\
1.00 & 8 & 16 \\
\hline \multicolumn{3}{c}{ P(MTABuI-co-HEMA) } \\
\hline 0.18 & 128 & 128 \\
0.37 & 128 & 128 \\
0.56 & 8 & 8 \\
0.76 & 8 & 8 \\
1.00 & 8 & 8 \\
\hline
\end{tabular}

Therefore, the obtained copolymers were demonstrated to be promising antimicrobial materials, in which the incorporation of even a low number of cationic units into PHEMA provided significant antibacterial activity and maintained good thermal stability. While higher amounts of the cationic monomer, up to $\sim 50 \%$, maintained the excellent antimicrobial activity, reaching MIC values similar to that found in the homopolymers PMTARI, and improved their thermal stability, the monomer could also enhance their biocompatibility, because PHEMA and PMTARI are not toxics [20,22,28,29].

\section{Materials and Methods}

\subsection{Materials}

The monomer 2-(4-methylthiazol-5-yl)ethyl methacrylate (MTA) was synthesized as previously reported [20]. The monomer 2-hydroxyethyl methacrylate (HEMA, 99\%; Aldrich, Steinheim, Germany) was distilled prior to use. 2,2'-Azobisisobutyronitrile (AIBN, 98\%; Acros, Buch, Switzerland) was recrystallized twice from methanol $(\mathrm{MeOH}, 99.9 \%$; Aldrich) prior to use. Anhydrous dimethyl sulfoxide (DMSO, 99.8\%) and $\mathrm{N}, \mathrm{N}$-dimethylformamide (DMF, 99.8\%) were purchased from Alfa-Aesar (Karlsruhe, Germany) and were used as received. 1-Iodobutane (BuI, 99\%, Aldrich), iodomethane (MeI, 99\%; Aldrich), and hexane (96\%; Scharlau, Sentmenat, Spain) were used as received.

For the microbiological assays, sodium chloride $(\mathrm{NaCl}, 0.9 \%$, BioXtra, Steinheim, Germany, suitable for cell cultures) and phosphate buffered saline (PBS, pH 7.4) were obtained from Aldrich. $\mathrm{BBL}^{\mathrm{TM}}$ Mueller Hinton broth used as microbial growth media was purchased from Becton, Dickinson and Company (Madrid, Spain). Sheep blood (5\%) and Columbia Agar plates were acquired from BioMérieux (Madrid, Spain). American Type Culture Collection (ATCC) Gram-positive Staphylococcus aureus (S. aureus, ATCC 29213) and Gram-negative Pseudomonas aeruginosa (P. aeruginosa, ATCC 27853) bacteria were obtained from Oxoid ${ }^{\mathrm{TM}}$ (Wesel, Germany).

\subsection{Synthesis of $P(M T A-c o-H E M A)$ Copolymers}

P(MTA-co-HEMA)s copolymers with different chemical compositions were synthesized via free radical polymerization of HEMA and MTA comonomers, as shown in Scheme 1. Briefly, both monomers, MTA and HEMA (1 M total concentration), and the initiator, AIBN $\left(5 \times 10^{-2} \mathrm{M}\right)$, were added into a Schlenk tube and dissolved in anhydrous DMSO. The mixture was deoxygenated by purging with argon over $15 \mathrm{~min}$. Then, the reaction was stirred at $60^{\circ} \mathrm{C}$ for $20 \mathrm{~h}$ under an argon atmosphere. After that, the mixture was cooled down, and the polymers were isolated by precipitation 
into distilled water, filtered, and washed several times with water. The solid was dried under a vacuum until a constant weight was reached.

P(MTA-co-HEMA): ${ }^{1} \mathrm{H}-\mathrm{NMR}(300 \mathrm{MHz}, \mathrm{DMSO}-\mathrm{d} 6): \delta=8.80-8.85$ (br, $1 \mathrm{H} ;=\mathrm{CH}$ thiazole, MTA), 4.80 (br, 1H; OH, HEMA), 4.02 (br, 2H; $\left.\mathrm{OCH}_{2}, \mathrm{MTA}\right), 3.90$ (br, 2H; - $\mathrm{CH}_{2}-\mathrm{OH}, \mathrm{HEMA}$ ), 3.59 (br, 2H; $-\mathrm{CH}_{2}-\mathrm{CO}-$, $\mathrm{HEMA}$ ), 3.05 (br, $\left.2 \mathrm{H} ; \mathrm{CH}_{2}, \mathrm{MTA}\right), 2.30$ (br, $3 \mathrm{H} ; \mathrm{CH}_{3}$ thiazole, MTA), 1.92-1.24 (br, $2 \mathrm{H} ; \mathrm{CH}_{2}$, MTA), $0.76-0.57$ (br, $3 \mathrm{H} ; \mathrm{CH}_{3}$, MTA).

\subsection{Quaternization of Copolymers: Synthesis of Cationic Polyelectrolytes, P(MTARI-co-HEMA)}

The P(MTA-co-HEMA) copolymers were modified by $N$-alkylation of the thiazole groups of the MTA units with 1-iodobutane or iodomethane, as shown in Scheme 2. The copolymers were added into a sealed tube containing a magnetic stirring bar and dissolved in anhydrous DMF $\left(0.1 \mathrm{mmol} \mathrm{L}{ }^{-1}\right)$. Then, a large excess of alkyl iodide, methyl iodide, or butyl iodide was added (ratio copolymer/alkyl iodide $\approx 1: 5$ ). The mixture was purged with argon and heated at $70{ }^{\circ} \mathrm{C}$ while being stirred for one week to ensure complete quaternization. Then, the solution was poured into hexane, and the copolymers were obtained as brown oils. The quaternized copolymers were further purified by dialysis against the distilled water to remove the residual products and were freeze dried. The methylated and butylated copolymers were labeled as P(MTAMeI-co-HEMA) and P(MTABuI-co-HEMA), respectively. The degree of quaternization was determined by ${ }^{1} \mathrm{H}-\mathrm{NMR}$ spectroscopy [22].

P(MTAMeI-co-HEMA): ${ }^{1} \mathrm{H}-\mathrm{NMR}(300 \mathrm{MHz}, \mathrm{DMSO}-\mathrm{d} 6): \delta=10.16-10.06(\mathrm{br}, 1 \mathrm{H} ;=\mathrm{CH}$ thiazolium, MTAMeI), 4.80 (br, 1H; OH, HEMA), 4.20-3.99 (br, 5H; ${ }^{+} \mathrm{NCH}_{3}$ and $\left.\mathrm{OCH}_{2}, \mathrm{MTAMeI}\right), 3.90$ (br, 2H; - $\mathrm{CH}_{2}-\mathrm{OH}$, HEMA), 3.59 (br, 2H; - $\mathrm{CH}_{2}-\mathrm{CO}-$, HEMA), 3.40 (br, 2H; $\mathrm{CH}_{2}, \mathrm{MTAMeI}$ ), 2.57 (br, 3H; $\mathrm{CH}_{3}$ thiazolium, MTAMeI), 2.14-1.47 (br, 2H; - $\mathrm{CH}_{2-}$, MTAMeI), 1.80 (br, 2H, - $\mathrm{CH}_{2-}$, HEMA), 1.10-0.60 (br, $\left.3 \mathrm{H} ; \mathrm{CH}_{3}, \mathrm{HEMA}\right) 1.07-0.41$ (br, 3H; $\mathrm{CH}_{3}$, MTAMeI).

P(MTABuI-co-HEMA): ${ }^{1} \mathrm{H}-\mathrm{NMR}\left(300 \mathrm{MHz}, \mathrm{DMSO}_{\mathrm{d}}\right.$ ): $\delta=10.27-10.10(\mathrm{br}, 1 \mathrm{H} ;=\mathrm{CH}$ thiazolium, MTABuI), 4.80 (br, 1H; OH, HEMA), 4.56-4.45 (br, 2H; $\left.{ }^{+} \mathrm{NCH}_{2}, \mathrm{MTABuI}\right), 4.09-4.02$ (br, 2H; $\mathrm{OCH}_{2}$, MTABuI), 3.90 (br, 2H; - $\left.\mathrm{CH}_{2}-\mathrm{OH}, \mathrm{HEMA}\right), 3.59$ (br, 2H; $-\mathrm{CH}_{2}-\mathrm{CO}-$, HEMA), 3.32 (br, $2 \mathrm{H} ; \mathrm{CH}_{2}$, MTABuI), 2.57 (br, 3H; $\mathrm{CH}_{3}$ thiazolium, MTABuI), 1.93-1.65 (br, 2H; $\left.\mathrm{CH}_{2}, \mathrm{MTABuI}\right), 1.80$ (br, 2H, - $\mathrm{CH}_{2}-$, HEMA), $1.10-0.60$ (br, 3H; $\left.\mathrm{CH}_{3}, \mathrm{HEMA}\right), 1.48-1.23$ (br, $\left.4 \mathrm{H} ; 2 \mathrm{CH}_{2}, \mathrm{MTABuI}\right), 0.98-0.34$ (br, $6 \mathrm{H}$; $\left.2 \mathrm{CH}_{3}, \mathrm{MTABuI}\right)$.

\subsection{Characterization Methods}

The ${ }^{1} \mathrm{H}$ nuclear magnetic resonance (NMR) spectra were recorded on a Varian System-500 at room temperature using deuterated chloroform $\left(\mathrm{CDCl}_{3}\right)$ and DMSO-d6 purchased from Sigma-Aldrich as solvents. Fourier-transform infrared (FTIR) spectra were recorded on a Perkin Elmer Spectrum Two instrument with a high-performance, room temperature $\mathrm{LiTaO}_{3}$ (lithium tantalate) detector and a universal attenuated total reflectance (ATR) instrument with a diamond/ZnSe crystal. The absorptions were given in wavenumber $\left(\mathrm{cm}^{-1}\right)$, and the spectrum was performed in scan range from 4000 to $450 \mathrm{~cm}^{-1}$ with a $0.5 \mathrm{~cm}^{-1}$ resolution and 16 scans. The molecular weights and polydispersity indexes of the synthetized copolymers were determined by gel permeation chromatography (GPC) on a Waters Division Millipore system and a Waters 2414 refractive index detector with a $1 \mathrm{~mL} / \mathrm{min}^{-1}$ flow rate of DMF (GPC-grade, stabilized with $0.1 \mathrm{M} \mathrm{LiBr}$, Scharlau) as eluent at $50{ }^{\circ} \mathrm{C}$. The calibration was performed with poly(methyl methacrylate) standards (Polymer Laboratories LTD). The zeta potential measurements were conducted using the Zetasizer Nano series ZS (Malvern Instruments Ltd, Malvern, UK). The zeta potential of the polymers in deionized water was an average of 10 measurements. Differential scanning calorimetry (DSC) measurements were conducted on a TA Q2000 instrument under dry nitrogen $\left(50 \mathrm{~cm}^{3} \mathrm{~min}^{-1}\right)$. The samples were equilibrated at $-70{ }^{\circ} \mathrm{C}$ and heated to $120^{\circ} \mathrm{C}$ at $10^{\circ} \mathrm{C} / \mathrm{min}$. Then, they were cooled to $-70{ }^{\circ} \mathrm{C}$ and again heated to $120^{\circ} \mathrm{C}$ at similar scanning rates. The thermogravimetric analysis (TGA) of the copolymers was performed on a TA Instrument (TGA Q500, TA Instruments, New Castle, Delaware, US) at a heating rate of $10^{\circ} \mathrm{C} / \mathrm{min}^{-1}$ from 40 to $800^{\circ} \mathrm{C}$ 
under a nitrogen atmosphere. The instrument was calibrated both for temperature and weight by standard methods.

\subsection{Microbial Growth Inhibition Assays}

The antimicrobial activity of the quaternized copolymers was tested against the ATCC microbial strains according to the Clinical Laboratory Standards Institute (CLSI) microbroth dilution reference methods $[42,43,46]$. The microorganisms were incubated on $5 \%$ sheep blood and Columbia Agar plates (BioMérieux) for $24 \mathrm{~h}$ at $37^{\circ} \mathrm{C}$ in a Jouan IQ050 incubator (Winchester, VA, USA). Then, the microorganism concentration was adjusted with a saline solution to a turbidity equivalent to ca. 0.5 of the McFarland turbidity standard, which corresponds to about $10^{8}$ colony-forming units (CFU) $\mathrm{mL}^{-1}$. The optical density of the microorganism suspensions was measured in a DensiCHEK ${ }^{\mathrm{TM}}$ Plus (VITEK, BioMérieux). These suspensions were further diluted with Mueller-Hinton broth to obtain $2 \times 10^{6} \mathrm{CFU} \mathrm{mL}{ }^{-1}$. The copolymers were dissolved in a mixture of sterile water and a minimum amount of DMSO (up to $6 \% v / v$ as a higher DMSO content was demonstrated to be toxic for these bacterial strains [20,47]) to obtain solutions of $256 \mu \mathrm{g} \mathrm{mL}^{-1}$ for each copolymer. Then, the broth microdilution method was carried out as follows: $100 \mu \mathrm{L}$ of each copolymer solution was placed in the first column of a 96-well round-bottom microplate. Subsequently, $50 \mu \mathrm{L}$ of broth was added into the rest of the wells (except in the first column). In the first column, $50 \mu \mathrm{L}$ of the copolymer solution was diluted by 2-fold serial dilutions in the rest of the wells, and finally, all the wells of the microdilution plates were inoculated with $50 \mu \mathrm{L}$ of each test microorganism sample to yield a total volume of $100 \mu \mathrm{L}$, bacterial concentrations of $5 \times 10^{5} \mathrm{CFU} \mathrm{mL}^{-1}$, and copolymer concentrations of $128,64,32,16,8,4,2$, $1,0.5,0.25$, and $0.125 \mu \mathrm{g} \mathrm{mL}^{-1}$. Positive and negative controls were also performed. The plates were incubated at $37^{\circ} \mathrm{C}$ for $24 \mathrm{~h}$, and the MIC was visually determined to be the lowest concentration of the antimicrobial copolymer in which no bacterial growth was observed. The tests were performed in triplicate.

Author Contributions: Conceptualization, M.F.-G.; Methodology, M.F.-G., A.M.-B. and D.L.; Validation, M.F.-G., A.M.-B. and D.L.; Formal Analysis, A.M.-B., D.L. and M.F.-G.; Original Draft Preparation, A.M.-B.; Review and Editing, M.F.-G.; and Funding Acquisition, M.F.-G.

Acknowledgments: This work was supported by grants from el Sistema Nacional de Garantía Juvenil: PEJ-2014-A-85575 and CM_MAD_ICTP_040 (Promoción de Empleo Joven e Implantación de la Garantía Juvenil, 2014 MINECO, and 2015 CSIC, respectively) and el Ministerio de Ciencia, Innovación y Universidades (Project MAT2016-78437-R), la Agencia Estatal de Investigación (AEI, Spain), and el Fondo Europeo de Desarrollo Regional (FEDER, EU). The authors would like to acknowledge Móstoles University Hospital for the assistance with the antimicrobial tests and Ms. M. González for the preparation of polymers.

Conflicts of Interest: The authors declare no conflicts of interest.

$\begin{array}{ll}\text { Abbreviations } & \\ \text { AIBN } & 2,2^{\prime} \text {-azobisisobutyronitrile } \\ \text { ATCC } & \text { American Type Culture Collection } \\ \text { br } & \text { broad } \\ \text { BuI } & \text { 1-iodobutane } \\ \mathrm{CDCl}_{3} & \text { deuterated chloroform } \\ \mathrm{CFU} & \text { colony-forming units } \\ \mathrm{CLSI} & \text { Clinical Laboratory Standards Institute } \\ \text { DMF } & \text { N,N-dimethylformamide } \\ \text { DMSO } & \text { dimethyl sulfoxide } \\ \text { DMSO-d6 } & \text { deuterated dimethyl sulfoxide } \\ \text { DSC } & \text { differential scanning calorimetry } \\ -\mathrm{dw} / \mathrm{dT} & \text { rate of weight loss } \\ \mathrm{f}_{\mathrm{MTA}} & \text { feed molar fraction of MTA } \\ \mathrm{F}_{\mathrm{MTA}} & \text { molar fraction of MTA in the copolymer }\end{array}$




$\begin{array}{ll}\text { GPC } & \text { gel permeation chromatography } \\ \text { HAI } & \text { hospital-acquired infections } \\ \text { HEMA } & \text { 2-hydroxyethyl methacrylate } \\ \text { MeOH } & \text { methanol } \\ \text { MeI } & \text { iodomethane } \\ \text { MIC } & \text { minimum inhibitory concentration } \\ \mathrm{M}_{\mathrm{n}} & \text { number average molecular weight } \\ \text { MTA } & \text { 2-(4-methylthiazol-5-yl)ethyl methacrylate } \\ \text { NMR } & \text { nuclear magnetic resonance } \\ \text { P. aeruginosa } & \text { Pseudomonas aeruginosa } \\ \text { PBS } & \text { phosphate buffered saline } \\ \text { PDI } & \text { polydispersity indexes } \\ \text { PHEMA } & \text { poly(2-hydroxyethyl methacrylate) } \\ \text { PMTA } & \text { poly(2-(4-methylthiazol-5-yl)ethyl methacrylate) } \\ \text { P(MTA-co-HEMA) } & \text { copolymers of HEMA with MTA } \\ \text { RI } & \text { alkyl iodide } \\ \text { S. aureus } & \text { Staphylococcus aureus } \\ \mathrm{T}_{\mathrm{d}} \text { max } & \text { temperature of maximum rate of weight loss } \\ \mathrm{T}_{\mathrm{d}} \text { onset } & \text { initial degradation temperature } \\ \text { TGA } & \text { thermogravimetric analysis } \\ \mathrm{T}_{\mathrm{g}} & \text { glass transition temperature }\end{array}$

\section{References}

1. Muñoz-Bonilla, A.; Fernández-García, M. Polymeric materials with antimicrobial activity. Prog. Polym. Sci. 2012, 37, 281-339. [CrossRef]

2. Huang, K.-S.; Yang, C.-H.; Huang, S.-L.; Chen, C.-Y.; Lu, Y.-Y.; Lin, Y.-S. Recent advances in antimicrobial polymers: A mini-review. Int. J. Mol. Sci. 2016, 17, 1578. [CrossRef] [PubMed]

3. Alvarez-Paino, M.; Munoz-Bonilla, A.; Fernandez-Garcia, M. Antimicrobial polymers in the nano-world. Nanomaterials 2017, 7, 48. [CrossRef] [PubMed]

4. Hong, K.H.; Sun, G. Structures and photoactive properties of poly(styrene-co-vinylbenzophenone). J. Polym. Sci. Part B Polym. Phys. 2008, 46, 2423-2430. [CrossRef]

5. Nishat, N.; Ahamad, T.; Zulfequar, M.; Hasnain, S. New antimicrobial polyurea: Synthesis, characterization, and antibacterial activities of polyurea-containing thiosemicarbazide-metal complexes. J. Appl. Polym. Sci. 2008, 110, 3305-3312. [CrossRef]

6. Francolini, I.; Vuotto, C.; Piozzi, A.; Donelli, G. Antifouling and antimicrobial biomaterials: An overview. Apmis 2017, 125, 392-417. [CrossRef] [PubMed]

7. Hickok, N.J.; Shapiro, I.M. Immobilized antibiotics to prevent orthopaedic implant infections. Adv. Drug Deliv. Rev. 2012, 64, 1165-1176. [CrossRef]

8. Gao, P.; Nie, X.; Zou, M.; Shi, Y.; Cheng, G. Recent advances in materials for extended-release antibiotic delivery system. J. Antibiot. 2011, 64, 625-634. [CrossRef]

9. Adlhart, C.; Verran, J.; Azevedo, N.F.; Olmez, H.; Keinanen-Toivola, M.M.; Gouveia, I.; Melo, L.F.; Crijns, F. Surface modifications for antimicrobial effects in the healthcare setting: A critical overview. J. Hosp. Infect. 2018, 99, 239-249. [CrossRef]

10. Kelly, M.; Williams, R.; Aojula, A.; O’Neill, J.; Trzinscka, Z.; Grover, L.; Scott, R.A.; Peacock, A.F.; Logan, A.; Stamboulis, A.; et al. Peptide aptamers: Novel coatings for orthopaedic implants. Mater. Sci. Eng. C Mater. Biol. Appl. 2015, 54, 84-93. [CrossRef]

11. Jo, Y.K.; Seo, J.H.; Choi, B.H.; Kim, B.J.; Shin, H.H.; Hwang, B.H.; Cha, H.J. Surface-independent antibacterial coating using silver nanoparticle-generating engineered mussel glue. ACS Appl. Mater. Interfaces 2014, 6, 20242-20253. [CrossRef] [PubMed]

12. Kubacka, A.; Ferrer, M.; Fernández-García, M.; Serrano, C.; Cerrada, M.L.; Fernández-García, M. Tailoring polymer- $\mathrm{TiO}_{2}$ film properties by presence of metal $(\mathrm{ag}, \mathrm{cu}, \mathrm{zn})$ species: Optimization of antimicrobial properties. Appl. Catal. B Environ. 2011, 104, 346-352. [CrossRef] 
13. De Lucas-Gil, E.; Reinosa, J.J.; Neuhaus, K.; Vera-Londono, L.; Martín-González, M.; Fernández, J.F.; Rubio-Marcos, F. Exploring new mechanisms for effective antimicrobial materials: Electric contact-killing based on multiple schottky barriers. ACS Appl. Mater. Interfaces 2017, 9, 26219-26225. [CrossRef]

14. Muñoz-Bonilla, A.; Cerrada, M.; Fernández-García, M.; Kubacka, A.; Ferrer, M.; Fernández-García, M. Biodegradable polycaprolactone-titania nanocomposites: Preparation, characterization and antimicrobial properties. Int. J. Mol. Sci. 2013, 14, 9249. [CrossRef] [PubMed]

15. Kubacka, A.; Cerrada, M.L.; Serrano, C.; Fernández-García, M.; Ferrer, M.; Fernández-García, M. Plasmonic nanoparticle/polymer nanocomposites with enhanced photocatalytic antimicrobial properties. J. Phys. Chem. C 2009, 113, 9182-9190. [CrossRef]

16. Siedenbiedel, F.; Tiller, J.C. Antimicrobial polymers in solution and on surfaces: Overview and functional principles. Polymers 2012, 4, 46-71. [CrossRef]

17. Jain, A.; Duvvuri, L.S.; Farah, S.; Beyth, N.; Domb, A.J.; Khan, W. Antimicrobial polymers. Adv. Healthc. Mater. 2014, 3, 1969-1985. [CrossRef]

18. Xue, Y.; Xiao, H.; Zhang, Y. Antimicrobial polymeric materials with quaternary ammonium and phosphonium salts. Int. J. Mol. Sci. 2015, 16, 3626-3655. [CrossRef] [PubMed]

19. Jiao, Y.; Niu, L.-N.; Ma, S.; Li, J.; Tay, F.R.; Chen, J.-H. Quaternary ammonium-based biomedical materials: State-of-the-art, toxicological aspects and antimicrobial resistance. Prog. Polym. Sci. 2017, 71, 53-90. [CrossRef]

20. Tejero, R.; Lopez, D.; Lopez-Fabal, F.; Gomez-Garces, J.L.; Fernandez-Garcia, M. Antimicrobial polymethacrylates based on quaternized 1,3-thiazole and 1,2,3-triazole side-chain groups. Polym. Chem. 2015, 6, 3449-3459. [CrossRef]

21. Tejero, R.; Gutiérrez, B.; López, D.; López-Fabal, F.; Gómez-Garcés, J.L.; Fernández-García, M. Copolymers of acrylonitrile with quaternizable thiazole and triazole side-chain methacrylates as potent antimicrobial and hemocompatible systems. Acta Biomater. 2015, 25, 86-96. [CrossRef] [PubMed]

22. Tejero, R.; López, D.; López-Fabal, F.; Gómez-Garcés, J.L.; Fernández-García, M. High efficiency antimicrobial thiazolium and triazolium side-chain polymethacrylates obtained by controlled alkylation of the corresponding azole derivatives. Biomacromolecules 2015, 16, 1844-1854. [CrossRef] [PubMed]

23. Cuervo-Rodriguez, R.; Lopez-Fabal, F.; Gomez-Garces, J.L.; Munoz-Bonilla, A.; Fernandez-Garcia, M. Contact active antimicrobial coatings prepared by polymer blending. Macromol. Biosci. 2017, 17, 1700258. [CrossRef]

24. Tejero, R.; Gutiérrez, B.; López, D.; López-Fabal, F.; Gómez-Garcés, J.; Muñoz-Bonilla, A.; Fernández-García, M. Tailoring macromolecular structure of cationic polymers towards efficient contact active antimicrobial surfaces. Polymers 2018, 10, 241. [CrossRef]

25. Munoz-Bonilla, A.; Cuervo-Rodriguez, R.; Lopez-Fabal, F.; Gomez-Garces, J.L.; Fernandez-Garcia, M. Antimicrobial porous surfaces prepared by breath figures approach. Materials 2018, 11, 1266. [CrossRef] [PubMed]

26. Jones, D.S.; McCoy, C.P.; Andrews, G.P.; McCrory, R.M.; Gorman, S.P. Hydrogel antimicrobial capture coatings for endotracheal tubes: A pharmaceutical strategy designed to prevent ventilator-associated pneumonia. Mol. Pharm. 2015, 12, 2928-2936. [CrossRef] [PubMed]

27. Myung, D.; Duhamel, P.-E.; Cochran, J.R.; Noolandi, J.; Ta, C.N.; Frank, C.W. Development of hydrogel-based keratoprostheses: A materials perspective. Biotechnol. Prog. 2008, 24, 735-741. [CrossRef] [PubMed]

28. Prasitsilp, M.; Siriwittayakorn, T.; Molloy, R.; Suebsanit, N.; Siriwittayakorn, P.; Veeranondha, S. Cytotoxicity study of homopolymers and copolymers of 2-hydroxyethyl methacrylate and some alkyl acrylates for potential use as temporary skin substitutes. J. Mater. Sci. Mater. Med. 2003, 14, 595-600. [CrossRef]

29. Allison, B.C.; Applegate, B.M.; Youngblood, J.P. Hemocompatibility of hydrophilic antimicrobial copolymers of alkylated 4-vinylpyridine. Biomacromolecules 2007, 8, 2995-2999. [CrossRef]

30. Halpenny, G.M.; Steinhardt, R.C.; Okialda, K.A.; Mascharak, P.K. Characterization of phema-based hydrogels that exhibit light-induced bactericidal effect via release of NO. J. Mater. Sci. Mater. Med. 2009, 20, 2353-2360. [CrossRef]

31. Ma, L.; Feng, S.; Fuente-Nunez, C.; Hancock, R.E.W.; Lu, X. Development of molecularly imprinted polymers to block quorum sensing and inhibit bacterial biofilm formation. ACS Appl. Mater. Interfaces 2018, 10, 18450-18457. [CrossRef] 
32. Vieira, A.P.; Pimenta, A.F.R.; Silva, D.; Gil, M.H.; Alves, P.; Coimbra, P.; Mata, J.; Bozukova, D.; Correia, T.R.; Correia, I.J.; et al. Surface modification of an intraocular lens material by plasma-assisted grafting with 2-hydroxyethyl methacrylate (HEMA), for controlled release of moxifloxacin. Eur. J. Pharm. Biopharm. 2017, 120, 52-62. [CrossRef] [PubMed]

33. Katritzky, A.R.; Ramsden, C.A.; Joule, J.A.; Zhdankin, V.V. Handbook of Heterocyclic Chemistry; Elsevier Science: Amsterdam, The Netherlands, 2010.

34. Bovey, F.A.; Mirau, P.A. (Eds.) 3-The solution characterization of polymers. In NMR of Polymers; Academic Press: San Diego, CA, USA, 1996; pp. 155-241.

35. Kuroda, K.; Caputo, G.A.; DeGrado, W.F. The role of hydrophobicity in the antimicrobial and hemolytic activities of polymethacrylate derivatives. Chem. Eur. J. 2009, 15, 1123-1133. [CrossRef] [PubMed]

36. Muñoz-Bonilla, A.; Fernández-García, M. The roadmap of antimicrobial polymeric materials in macromolecular nanotechnology. Eur. Polym. J. 2015, 65, 46-62. [CrossRef]

37. Çaykara, T.; Özyürek, C.; Kantoğlu, Ö. Investigation of thermal behavior of poly(2-hydroxyethyl methacrylate-co-itaconic acid) networks. J. Appl. Polym. Sci. 2006, 103, 1602-1607. [CrossRef]

38. Demirelli, K.; Coşkun, M.; Kaya, E. A detailed study of thermal degradation of poly(2-hydroxyethyl methacrylate). Polym. Degrad. Stab. 2001, 72, 75-80. [CrossRef]

39. Vargün, E.; Usanmaz, A. Degradation of poly(2-hydroxyethyl methacrylate) obtained by radiation in aqueous solution. J. Macromol. Sci. Part A 2010, 47, 882-891. [CrossRef]

40. Fernandez-Garcia, M.; Torrado, M.F.; Martinez, G.; Sanchez-Chaves, M.; Madruga, E.L. Free radical copolymerization of 2-hydroxyethyl methacrylate with butyl methacrylate: Determination of monomer reactivity ratios and glass transition temperatures. Polymer 2000, 41, 8001-8008. [CrossRef]

41. CLSI. Methods for Dilution Antimicrobial Susceptibility Tests for Bacteria That Grow Aerobically; Approved Standard-Ninth Edition; CLSI Document M07-A9; Clinical and Laboratory Standards Institute: Wayne, PA, USA, 2012.

42. CLSI. Performance Standards for Antimicrobial Susceptibility Testing; Twenty-Second Informational Supplement; CLSI Document M100-S22; Clinical and Laboratory Standards Institute: Wayne, PA, USA, 2012.

43. Kong, H.; Jang, J. Synthesis and antimicrobial properties of novel silver/polyrhodanine nanofibers. Biomacromolecules 2008, 9, 2677-2681. [CrossRef]

44. Takahashi, H.; Palermo, E.F.; Yasuhara, K.; Caputo, G.A.; Kuroda, K. Molecular design, structures, and activity of antimicrobial peptide-mimetic polymers. Macromol. Biosci. 2013, 13, 1285-1299. [CrossRef]

45. Takahashi, H.; Caputo, G.A.; Vemparala, S.; Kuroda, K. Synthetic random copolymers as a molecular platform to mimic host-defense antimicrobial peptides. Bioconjug. Chem. 2017, 28, 1340-1350. [CrossRef] [PubMed]

46. CLSI. Reference Method for Broth Dilution Antifungal Susceptibility Testing of Yeasts, Fourth Informational Supplement; CLSI Document M27-S4; Clinical and Laboratory Standards Institute: Wayne, PA, USA, 2012.

47. Alvarez-Paino, M.; Munoz-Bonilla, A.; Lopez-Fabal, F.; Gomez-Garces, J.L.; Heuts, J.P.; Fernandez-Garcia, M. Effect of glycounits on the antimicrobial properties and toxicity behavior of polymers based on quaternized DMAEMA. Biomacromolecules 2015, 16, 295-303. [CrossRef] [PubMed]

(C) 2018 by the authors. Licensee MDPI, Basel, Switzerland. This article is an open access article distributed under the terms and conditions of the Creative Commons Attribution (CC BY) license (http://creativecommons.org/licenses/by/4.0/). 